\title{
Świadomość wyboru zdrowych produktów spożywczych wśród studentów pielęgniarstwa
}

\author{
Healthy choice of food products among nursing students
}

MONIKA SANDER-GRABOWSKA ${ }^{1}$, BEATA PRZYSTAŚ 1 , ANNA ANTCZAK-KOMOTERSKA ${ }^{2}$

\footnotetext{
1 Studenckie Koło Naukowe Nauk o Zdrowiu, Instytut Nauk o Zdrowiu PWSZ we Włocławku, opiekun Koła: dr Beata Haor

2 Instytut Nauk o Zdrowiu PWSZ we Włocławku
}

DOI: http://dx.doi.org/10.21784/IwP.2018.021

ISSN: 2451-1846

\section{Streszczenie:}

Wstęp. Jednym z ważnych czynników wpływających na zdrowie człowieka jest prawidłowe odżywianie.

Cel. Celem pracy była analiza świadomości wyboru produktów spożywczych pozytywnie wpływających na zdrowie wśród studentów pierwszego roku kierunku pielęgniarstwo.

Materiał i metody. Do badań wykorzystano metodę sondażu diagnostycznego, a jako narzędzie badawcze kwestionariusz Inwentarza Zachowań Zdrowotnych (IZZ). Badania zostały przeprowadzone wśród studentów pierwszego roku kierunku pielęgniarstwo.

Wyniki. Z analizy przeprowadzonych badań wynika, że w większości studenci są świadomi wpływu wyboru zdrowych produktów spożywczych na zachowanie zdrowia. 
Wnioski. Studenci w przedziale wiekowym 20-25 lat i 31 lat i więcej jedzą więcej warzyw i owoców oraz unikają żywności $\mathrm{z}$ konserwantami. Najmłodsza grupa osób spożywa więcej pieczywa pełnoziarnistego oraz ogranicza spożycie soli i tłuszczów zwierzęcych.

Słowa kluczowe: produkty spożywcze, studenci, zdrowie

Abstract:

Introduction. Proper diet is one of the most important health determinants.

Aim. The aim of the work was to analyze healthy choice of food products that enhances health among first-year nursing students.

Material and Methods. The study used the diagnostic survey method as well as the Inventory of Health Behavior (IZZ) questionnaire as a research tool. The research was conducted among first-year nursing students.

Results. The analysis of the conducted research shows that in most cases students are aware of the impact of healthy choice of food products on health behavior.

Conclusions. Students in the age group of 20-25 year-olds and 31 year- olds and more eat more vegetables and fruit and avoid food with preservatives. The youngest group of people consumes more whole meal bread and reduces salt and animal fats consumption.

Key words: food products, students, health

\section{Wstęp}

Według Światowej Organizacji Zdrowia (WHO), zdrowie to stan pełnego, dobrego samopoczucia fizycznego, psychicznego i społecznego, a nie tylko brak choroby. Styl życia w 50\% wpływa na nasze zdrowie. Pozostałe czynniki to: środowisko (20\%), czynniki genetyczne (20\%), opieka zdrowotna (10\%) [1].

Prawidłowe odżywianie sprzyja zdrowiu i dobremu samopoczuciu, wpływa na system immunologiczny oraz funkcjonowanie wszystkich układów. Obniża także ryzyko wystąpienia chorób, nadwagi i otyłości oraz przewlekłych chorób dietozależnych, czyli cukrzycy typu 2 i chorób układu krążenia. 
Pełnowartościowa, całodzienna dieta powinna uwzględniać produkty z różnych grup takich, jak:

- Mleko i produkty mleczne zawierające łatwo przyswajalne białko, wapń, witaminy z grupy $\mathrm{B}$

- Mięso jako ważne źródło białka, witamin $\left(\mathrm{B}_{1}, \mathrm{~B}_{12}, \mathrm{PP}\right)$ oraz żelaza i cynku

- Ryby będące źródłem nienasyconych kwasów tłuszczowych

- Produkty zbożowe zawierające węglowodany złożone, witaminy z grupy B oraz składniki mineralne takie jak fosfor, wapń, magnez, selen

- Warzywa, które są źródłem węglowodanów, cukrów prostych, błonnika, składników mineralnych i witamin

- Owoce jako źródło cukrów prostych, dwucukrów, wielocukrów, witamin

- Tłuszcze spożywcze będące mieszaniną nasyconych i nienasyconych kwasów tłuszczowych, witamin rozpuszczalnych w tłuszczach $(A, D, E, K)$ i stanowiące źródło energii [2].

Już w czasach starożytnych wiadomo było, że najistotniejszym czynnikiem determinującym stan zdrowia jest sposób odżywiania się [3].

Prewencja chorób cywilizacyjnych skupia się przede wszystkim na promocji zachowań prozdrowotnych, w tym zdrowego i racjonalnego odżywiania się, systematycznej aktywności fizycznej oraz wykonywania okresowych badań przesiewowych [4].

Celem pracy jest analiza świadomości wyboru zdrowych produktów żywnościowych studentów pierwszego roku kierunku pielęgniarstwo.

\section{Materiał i metody}

Badania przeprowadzono wśród 22 studentów I roku kierunku pielęgniarstwo (studia stacjonarne) w Państwowej Wyższej 
Szkole Zawodowej we Włocławku w roku akademickim 2017/2018. $\mathrm{W}$ badaniu wykorzystano metodę sondażu diagnostycznego oraz metodę szacowania, a także technikę ankietowania i technikę skali szacunkowej. Jako narzędzie badawcze wykorzystano Kwestionariusz Inwentarza Zachowań Zdrowotnych (IZZ), zakupiony w Pracowni Testów Psychologicznych. Analizie poddano odpowiedzi respondentów odnoszące się do nawyków żywieniowych. Udział w badaniach był anonimowy i dobrowolny. Dane zebrano w arkuszu kalkulacyjnym Microsoft Excel 2003; określono udział procentowy odpowiedzi, a także liczbę punktów i ich średnią uzyskaną przez badanych. Wyniki zostały przedstawione w formie rycin i tabel.

$\mathrm{W}$ badanej grupie przeważały osoby $\mathrm{w}$ przedziale wiekowym 19 lat i mniej oraz 31 lat i więcej, odpowiednio 36,36\% (8 osób) i 36,36\% (8 osób). Respondenci w wieku 20-25 stanowili 27,27\% badanych (6 osób). Wśród studentów nie było żadnej osoby w przedziale wiekowym 26-30 lat (rycina 1 i 2).

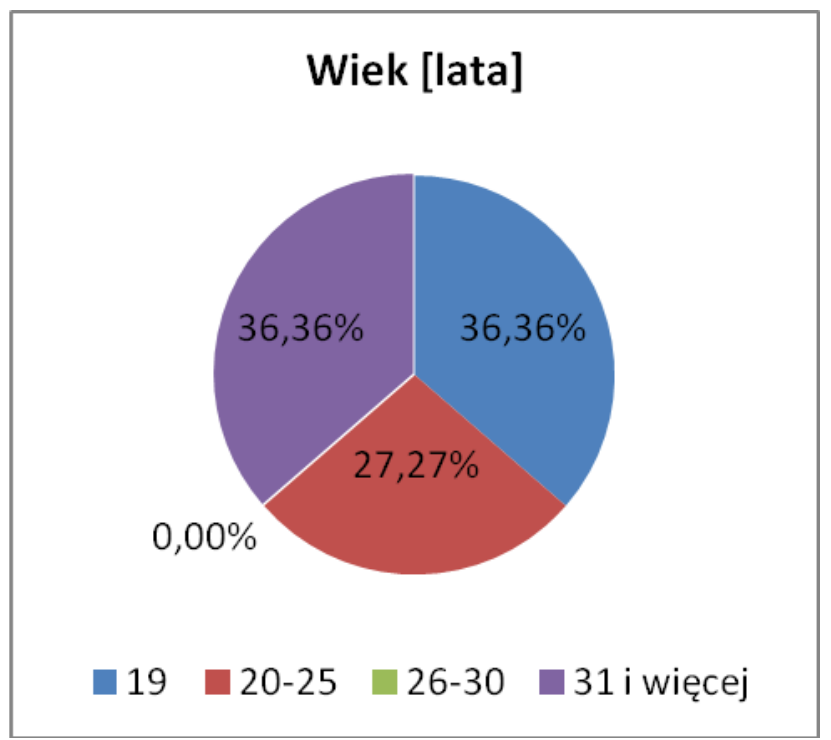

\section{Rycina 1. Wiek badanej grupy.}

Źródło: wynik badań własnych 


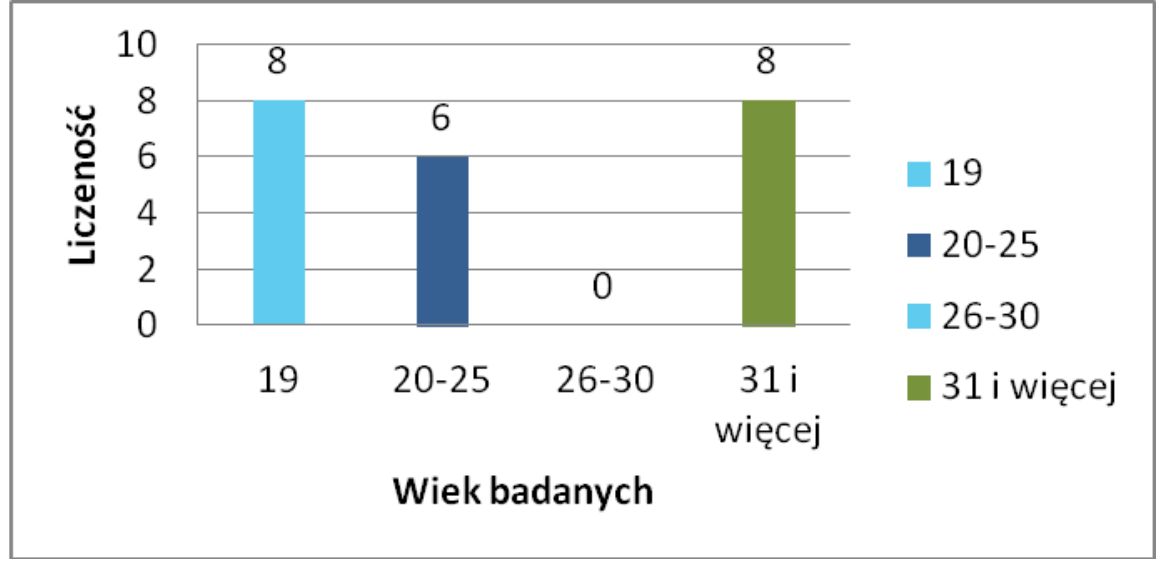

Rycina 2. Liczebność badanej grupy.

Źródło: wynik badań własnych

Analizie poddano odpowiedzi respondentów na następujące pytania:

1. Czy jem dużo warzyw, owoców?

2. Czy ograniczam spożywanie takich produktów, jak tłuszcze zwierzęce, cukier?

3. Czy dbam o prawidłowe odżywianie?

4. Czy unikam spożywania żywności z konserwantami?

5. Czy unikam soli i silnie solonej żywności?

6. Czy jem pieczywo pełnoziarniste?

Badani udzielali odpowiedzi wybierając ich następujące warianty: prawie nigdy, rzadko, od czasu do czasu, często, prawie zawsze.

\section{Wyniki}

Tabela 1 przedstawia sposób odżywiania studentów z podziałem na kategorie wiekowe. Największą liczbę punktów w tym zakresie uzyskiwali studenci z grupy wiekowej 20-25 lat.

Osoby w wieku 20-25 lat zebrali największą liczbę punktów odpowiadając na pytania: ograniczam tłuszcze zwierzęce i cukier 
(4 pkt.), dbam o prawidłowe odżywianie (4 pkt.), unikam soli i silnie solonej żywności (4 pkt.), jem pieczywo pełnoziarniste (4,5 pkt.). W grupie wiekowej 31 lat i więcej studenci uzyskali największą liczbę punktów odpowiadając na pytania: jem dużo warzyw i owoców (4,2 pkt.), unikam spożywania żywności z konserwantami (3,5 pkt.). Najniższą ilość punktów zdobyli studenci w wieku 19 lat i poniżej udzielając odpowiedzi następujące na pytania: jem dużo warzyw i owoców - 3,62 pkt., dbam o prawidłowe odżywianie - 3,25 pkt., jem pieczywo pełnoziarniste - 3 pkt., unikam spożywania żywności z konserwantami oraz unikam soli i silnie solonej żywności odpowiednio po 2,75 pkt., ograniczam spożywanie takich produktów, jak tłuszcze zwierzęce, cukier - 2,5 pkt. (rycina 3, tabela 1 ).

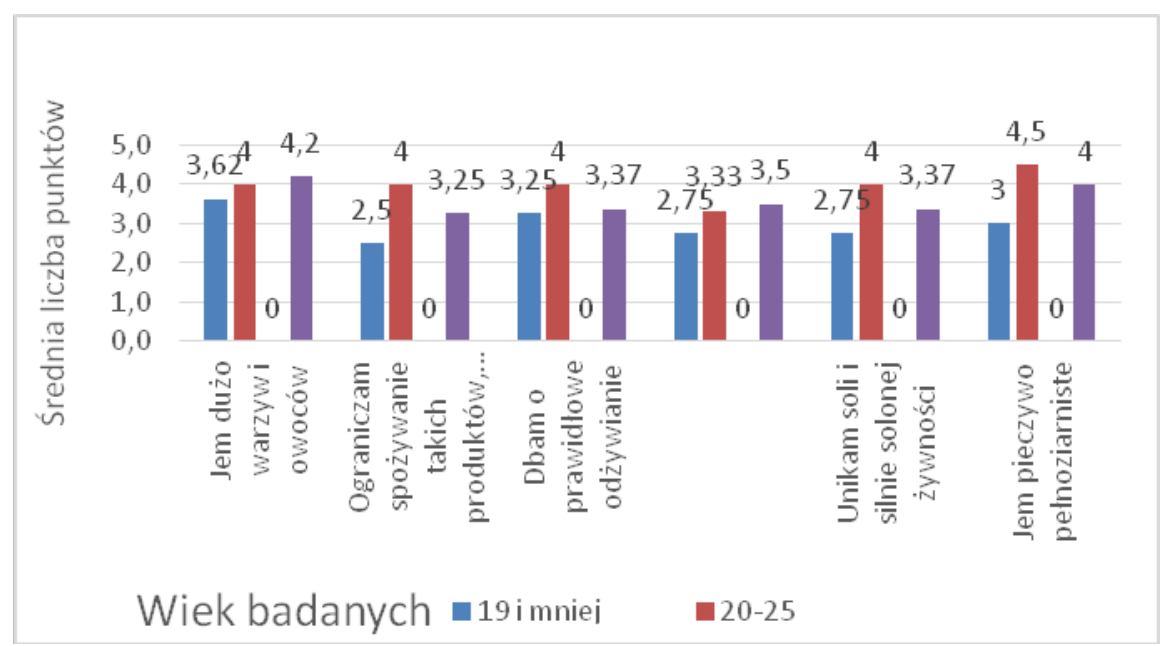

Rycina 3. Preferencje żywieniowe badanych ze względu na wiek.

Źródło: wynik badań własnych 
Tabela 1. Preferencje żywieniowe badanych ze względu na wiek.

\begin{tabular}{|c|c|c|c|c|c|c|}
\hline $\begin{array}{l}\text { Kateg } \\
\text { oria } \\
\text { zacho } \\
\text { wań }\end{array}$ & \multicolumn{6}{|c|}{ Nawyki żywieniowe } \\
\hline $\begin{array}{l}\mathrm{Nr} \\
\text { pytania }\end{array}$ & 1 & 5 & 9 & 13 & 17 & 21 \\
\hline $\begin{array}{l}\text { Treść } \\
\text { pytani } \\
\text { a }\end{array}$ & $\begin{array}{l}\text { Jem } \\
\text { dużo } \\
\text { warzy } \\
\text { w, } \\
\text { owocó } \\
\text { w }\end{array}$ & $\begin{array}{l}\text { Ograni } \\
\text { czam } \\
\text { spoży } \\
\text { wanie } \\
\text { takich } \\
\text { produk } \\
\text { tów, } \\
\text { jak } \\
\text { tłuszcz } \\
\text { e } \\
\text { zwierz } \\
\text { ęce, } \\
\text { cukier }\end{array}$ & $\begin{array}{l}\text { Dbam } \\
\text { o } \\
\text { prawid } \\
\text { łowe } \\
\text { odżywi } \\
\text { anie }\end{array}$ & $\begin{array}{l}\text { Unika } \\
\mathrm{m} \\
\text { spoży } \\
\text { wania } \\
\text { żywno } \\
\text { ści z } \\
\text { konser } \\
\text { wanta } \\
\text { mi }\end{array}$ & $\begin{array}{l}\text { Unika } \\
\text { m soli i } \\
\text { silnie } \\
\text { solonej } \\
\text { żywno } \\
\text { ści }\end{array}$ & $\begin{array}{l}\text { Jem } \\
\text { pieczy } \\
\text { wo } \\
\text { pełnozi } \\
\text { arniste }\end{array}$ \\
\hline $\begin{array}{l}\text { Wiek } \\
\text { [lata] }\end{array}$ & \multicolumn{6}{|c|}{ Średnia liczba punktów } \\
\hline $\begin{array}{l}19 \\
\text { mniej }\end{array}$ & 3,62 & 2,5 & 3,25 & 2,75 & 2,75 & 3,0 \\
\hline $20-25$ & 4,0 & 4,0 & 4,0 & 3,33 & 4,0 & 4,5 \\
\hline $26-30$ & 0 & 0 & 0 & 0 & 0 & 0 \\
\hline $\begin{array}{l}31 \quad \mathrm{i} \\
\text { więcej }\end{array}$ & 4,2 & 3,25 & 3,37 & 3,5 & 3,37 & 4,0 \\
\hline
\end{tabular}

Źródło: wynik badań własnych 
Jak wynika $\mathrm{z}$ ryciny 4, ponad połowa ankietowanych ze wszystkich grup wiekowych często spożywa warzywa i owoce. W najmłodszej grupie wiekowej jedynie 1 osoba (12,5\%) odpowiedziała, że czyni to rzadko. W przedziale wiekowym 19 i mniej prawie zawsze sięga po owoce i warzywa $12,5 \%$ (1 osoba), w przedziale $20-25$ lat $-16,67 \%$ ( 1 osoba), natomiast w najstarszej grupie wiekowej 31 i więcej - 37,5\% (3osoby).

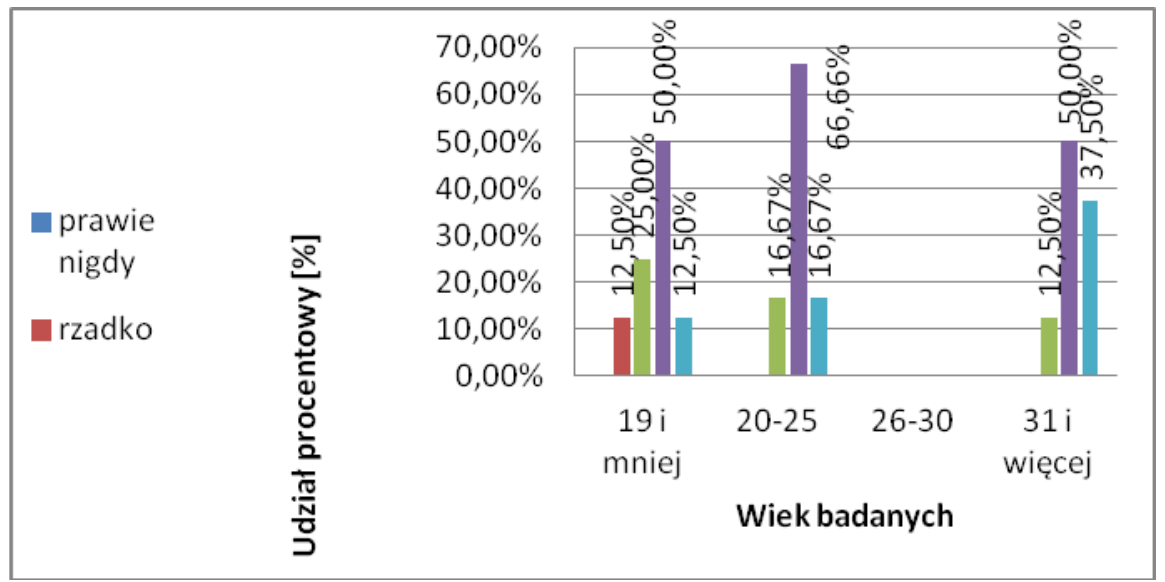

Rycina 4. Jem dużo warzyw, owoców.

Źródło: wynik badań własnych

Dalszej analizie poddano ograniczenie spożycia takich produktów, jak tłuszcze zwierzęce i cukier. Tutaj odpowiedzi nie były jednoznaczne. Połowa 19-latków nie ogranicza spożycia tych produktów. Natomiast pozostali respondenci czynią to tylko okazjonalnie a jedynie 1 osoba (12,5\%) - często. Większą świadomość w tym zakresie posiadają 20-25-latki bowiem 66,66\% (6 osób) ogranicza spożycie tłuszczów zwierzęcych i cukru zawsze lub prawie zawsze. Z kolei 33,33\% badanych (2 osoby) robi to od czasu do czasu. Rzadko lub tylko od czasu do czasu zadeklarowała ograniczenie 
spożycia tłuszczów i cukru połowa 31-latków, a 37,5\% (3 osoby) czyni to często (rycina 5).

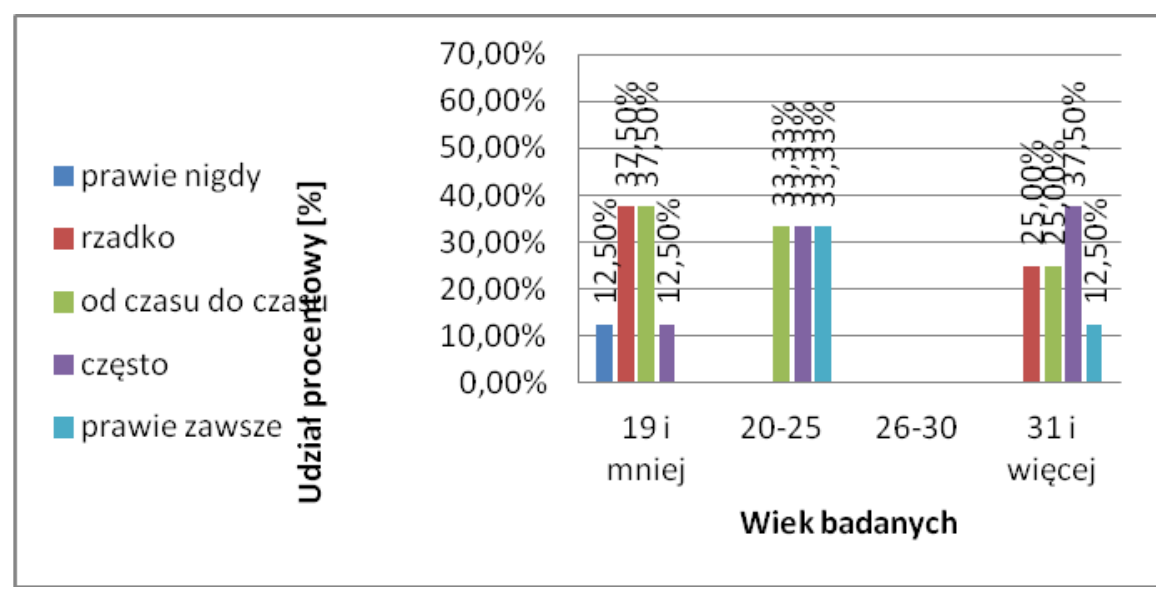

Rycina 5. Ograniczam spożywanie takich produktów, jak tłuszcze zwierzęce, cukier.

Źródło: wynik badań własnych

Prawidłowo odżywia się jedynie 37,5\% 19-latków (3 osoby), natomiast $25 \% \mathrm{z}$ nich ( 2 osoby) nie robi tego wcale. Zdecydowana większość respondentów (62,5\%) z grupy wiekowej 31 i więcej (5 osób) odżywia się prawidłowo, a jedynie 1 osoba (12,5\%) odpowiedziała, że nie robi tego prawie nigdy. W grupie wiekowej 2025 lat odpowiedzi rozłożyły się równomiernie - po 33,33\% - 2 osoby dbają o prawidłowe odżywianie od czasu do czasu, 2 osoby czynią to często a 2 osoby prawie zawsze (rycina 6). 


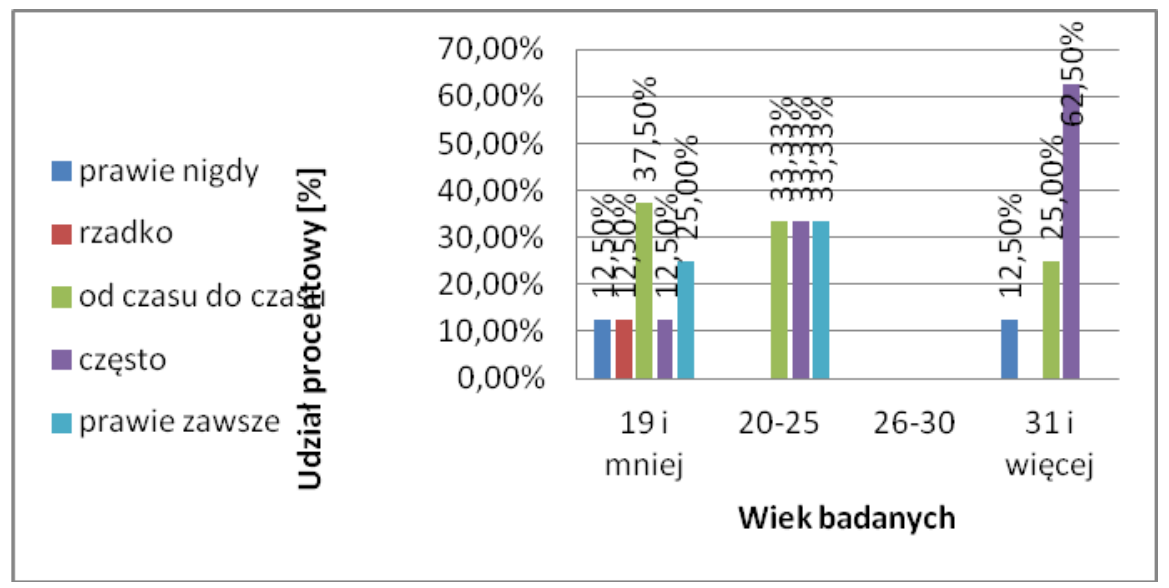

Rycina 6. Dbam o prawidłowe odżywianie.

Źródło: wynik badań własnych

Rycina 7 przedstawia preferencje żywieniowe respondentów dotyczące unikania spożywania żywności z konserwantami. Większość 19-latków (62,5\% -5 osób) robi to od czasu do czasu, bądź często unika żywności przetworzonej, prawie zawsze czyni to 33,33\% (2 osoby) 20-25-latków. Połowa studentów w badanej grupie w wieku 20-25 lat (3 osoby) korzysta $\mathrm{z}$ takiej żywności od czasu do czasu. Żywność z konserwantami spożywa 25\% respondentów (2 osoby) w przedziale wiekowym 31 lat i więcej. 


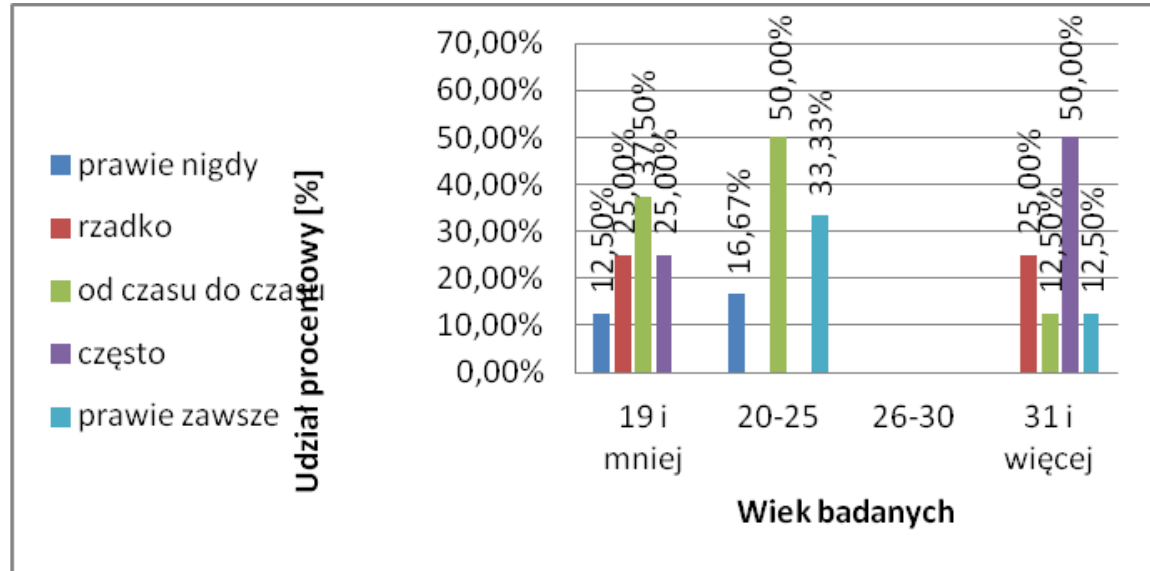

Rycina 7. Unikam spożywania żywności z konserwantami.

Źródło: wynik badań własnych

Jak wynika z ryciny 8 - 25\% 19-latków (2 osoby), 33,33\% 2025-latków (2 osoby) i 50\% 31-latów (4 osoby) odpowiedziała, że często unika spożywania soli i silnie solonej żywności. Prawie nigdy lub rzadko czyni to $25 \%$ 19-latków ( 2 osoby) i 1 student w grupie 31latków (12,5\%) (rycina 8).

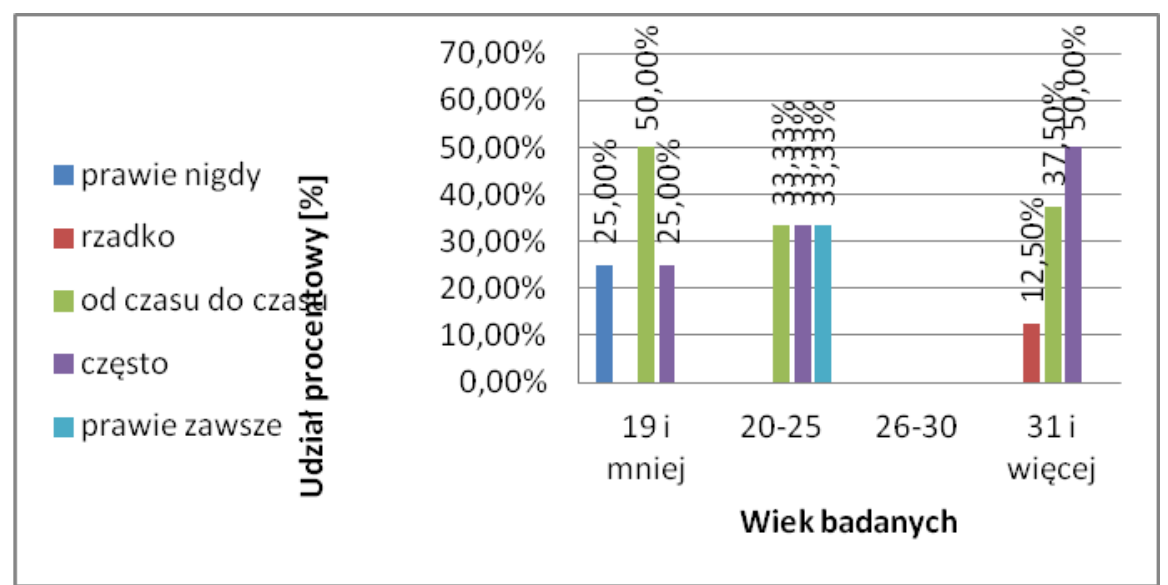

Rycina 8. Unikam soli i silnie solonej żywności.

Źródło: wynik badań własnych 
Pytanie dotyczące spożywania pieczywa pełnoziarnistego było ostatnim z pytań w ankiecie poddanych analizie. Najwięcej osób, które nie sięga po pieczywo z ziarnem dotyczyło najmłodszej i najstarszej grupy respondentów - odpowiednio 12,5\% (1 osoba) i 25\% (2 osoby). Ponad połowa 19-latków (62,5\%- 5 osób) spożywa takie pieczywo jedynie okazjonalnie. Wszyscy respondenci z przedziału wiekowego 20-25 lat jedzą pieczywo pełnoziarniste, natomiast w najstarszej grupie czyni to $62,5 \%$ badanych (5 osób) (rycina 9).

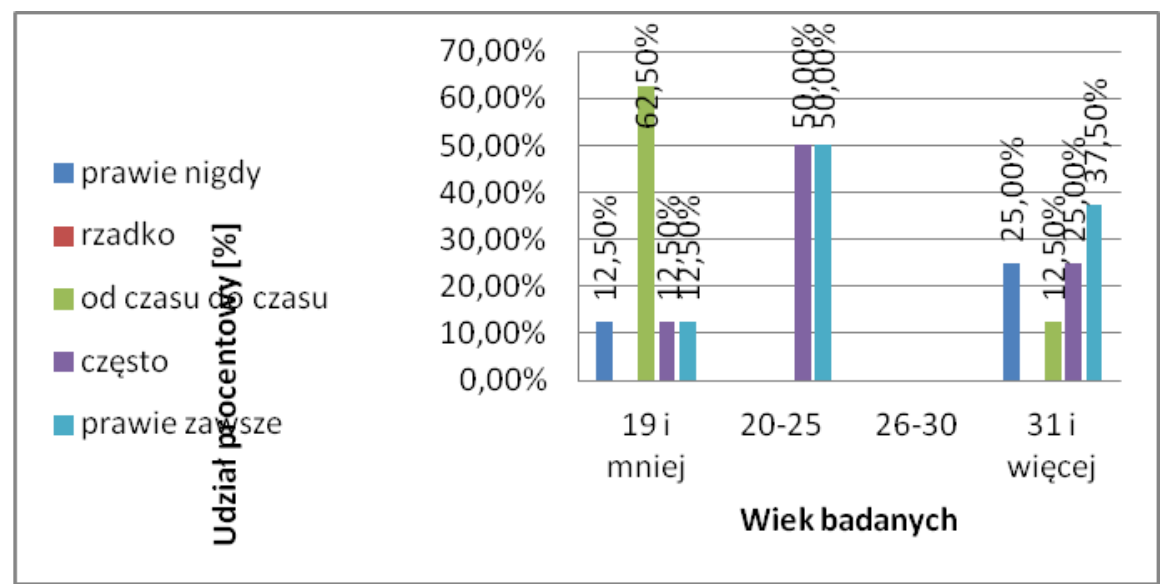

Rycina 9. Jem pieczywo pełnoziarniste.

Źródło: wynik badań własnych

\section{Dyskusja}

Wyniki badań z zastosowaniem kwestionariusza (IZZ) wykazują, że studenci I roku kierunku pielęgniarstwo reprezentują zróżnicowany poziom zachowań prozdrowotnych, z tendencją do zwracania uwagi na styl życia, a w szczególności na zdrowy sposób odżywiania. Jest to bardzo istotne z punktu widzenia wykonywanego w przyszłości zawodu. Od przedstawicieli zawodów medycznych wymaga się bowiem wiedzy i kompetencji w kształtowaniu 
prawidłowych nawyków mających wpływ na zdrowie człowieka. Edukacja społeczeństwa w zakresie zdrowego stylu życia odbywa się także dzięki mediom oraz programom profilaktycznym i kampaniom społecznym [5].

Jak wynika z przeprowadzonych badań własnych respondenci mają świadomość wpływu wyboru zdrowych produktów żywnościowych na zdrowie i starają się przestrzegać tych zasad na co dzień jedząc owoce i warzywa, pełnoziarniste pieczywo, ograniczając spożycie produktów zawierających: tłuszcze zwierzęce, cukier, sól, konserwanty.

Z badań WOBASZ (Wieloośrodkowe ogólnopolskie badanie stanu zdrowia ludności) wynika, że spożycie tłuszczów wśród ludności w Polsce, znacznie przekracza zalecaną dawkę dziennego zapotrzebowania, natomiast korzystanie z produktów zbożowych jest niższe od zalecanego. Jedynie spożycie owoców i warzyw w większości badanych województw można uznać za zadowalające, ponieważ przekroczyło ono minimalną zalecaną dawkę (400g) [6]. Z badań GUS (Główny Urząd Statystyczny) z 2014r. wynika, że spożycie owoców deklarowało 59\% a warzyw 57\% dorosłych mieszkańców Polski [7]. Dane WOBASZ i GUS wskazują jednak na to, że spożycie warzyw i owoców jest nadal niewystarczające wśród polskiej ludności.

Ponieważ studenci podczas dalszej nauki będą kształtowali kompetencje $\mathrm{w}$ zakresie promowania prawidłowych zachowań prozdrowotnych, powinni oni zwrócić szczególną uwagę na działania mające na celu zwiększenie spożycia owoców i warzyw. Prowadzenie prawidłowego stylu życia należy rozpocząć od siebie, rodziny i najbliższego otoczenia, co będzie miało przełożenie na wzrost świadomości społeczeństwa w tym zakresie [8].

Działania zmierzające do zmiany zachowań zdrowotnych polskiej populacji zostały uwzględnione $w$ założeniach NPZ (Narodowy Program Zdrowia na lata 2016-2020), którego cele 
operacyjne obejmują: poprawę sposobu żywienia, stanu odżywiania oraz promocję aktywności fizycznej wśród Polaków [9].

\section{Wnioski}

Przeprowadzone badanie pozwoliły na sformułowanie następujących wniosków:

1. Osoby w przedziale wiekowym 20-25 lat i 31 lat i więcej, jedzą więcej warzyw i owoców oraz unikają żywności z konserwantami.

2. Najmłodsza grupa studentów spożywa więcej pieczywa pełnoziarnistego oraz ogranicza spożycie soli i tłuszczów zwierzęcych.

3. Wszystkie grupy badanych wykazują wiedzę na temat wpływu prawidłowego odżywiania na stan zdrowia.

4. Nie odnotowano statystycznie istotnej różnicy pomiędzy miejscem odczuwanych dolegliwości bólowych a nasileniem bólu.

\section{Zalecenia dla praktyki pielęgniarskiej}

Studenci pielęgniarstwa wybierający zdrowe produkty żywnościowe będą w stanie w przyszłości propagować wśród swoich pacjentów pozytywne postawy w zakresie racjonalnego żywienia.

\section{Bibliografia / Bibliography:}

1. Heszen I, Sęk H, Psychologia zdrowia, PWN, Warszawa 2007.

2. Woynarowska B, Edukacja zdrowotna, PWN, Warszawa 2017; 359-362.

3. Gawęcki J, Roszkowski W, Żywienie człowieka, a zdrowie publiczne, T. 3, PWN, Warszawa 2009; 5. 
4. Gawęcki J, Roszkowski W. Żywienie człowieka a Zdrowie Publiczne. T. 3. PWN, Warszawa 2009; 223-228.

5. Dobrzyński B, Dziad A, Nazar K, Prozdrowotne wychowanie dzieci i młodzieży, Warszawa 1998.

6. Sygnatowska E, Waśkiewicz A, Gałuszek J, Spożycie produktów spożywczych przez dorosłą populację Polski. Wyniki programu WOBASZ, Kardiologia polska 2005; 57.

7. GUS, Stan zdrowia ludności Polski w 2014r., Warszawa 2016; 88-89.

8. Wojnowska B, Edukacja zdrowotna, Warszawa 2017.

9. Dziennik Ustaw Rzeczypospolitej Polskiej w dnia 16 września 2016r. poz. 1492. 